\title{
IMPLEMENTASI KEBIJAKAN AKUNTASI PEMERINTAH BASIS AKRUAL DALAM MANAJEMEN ASET TETAP SATUAN KERJA
}

\author{
LUGAS BRILLIAN \\ Politeknik Keuangan Negara STAN \\ 4301180036_lugas@pknstan.ac.id \\ AGUS SUNARYA SULAEMAN \\ Politeknik Keuangan Negara STAN \\ asunarya@pknstan.ac.id
}

Article History:

Received: 8 Juli 2021

Revised: 6 September 2021

Accepted: 7 September 2021

DOI: $10.29303 /$ jaa.v6i1.108
Abstract: Every fixed asset owned and/or controlled by the central government work unit is part of the state assets which will be presented in Financial Report of Central Government. Accounting for fixed assets to produce $L K P P$ is carried out on a cash basis as regulated in Technical Bulletin 15 concerning Accrual-Based Fixed Asset Accounting. The formulation of the problem discussed is the implementation of accounting policies starting from the classification, recognition, measurement, depreciation, as well as the presentation and disclosure of fixed assets in government work units. The aim is to see the accuracy of the implementation of fixed asset accounting policies in government work units. The government work unit that is the object of research is the regional office of one of the ministries in Lampung Province. Research data retrieval is done by interview and document method.

Abstrak: Setiap aset tetap dimiliki dan/atau dikuasai oleh satuan kerja pemerintah pusat merupakan bagian dari kekayaan negara yang akan disajikan dalam Laporan Keuangan Pemerintah Pusat. Akuntansi aset tetap hingga menghasilkan LKPP dilakukan dengan basis kas yang diatur dalam Buletin Teknis 15 tentang Akuntansi Aset Tetap Berbasis Akrual. Rumusan masalah yang dibahas adalah implementasi kebijakan akuntansi mulai dari klasifikasi, pengakuan, pengukuran, penyusutan, serta penyajian dan pengungkapan aset tetap pada satuan kerja pemerintah. Adapun tujuannya adalah untuk melihat keakuratan implementasi kebijakan akuntansi aset tetap pada satuan kerja pemerintah. Satuan kerja pemerintah yang menjadi objek penelitian adalah kantor daerah dari salah satu kementerian yang berada di 


\section{JAA}

Vol. 6, No. 1, Oktober 2021

Provinsi Lampung. Pengambilan data penelitian dilakukan dengan metode wawancara dan dokumen.

\section{Keyword : Government Accounting, Accrual Basis, Fixed Assets Kata kunci : Akuntansi Pemerintahan, Basis Akrual, Aset Tetap}

\section{PENDAHULUAN}

Menurut Peraturan Pemerintah Nomor 28 Tahun 2020 tentang Perubahan atas Peraturan Pemerintah Nomor 27 Tahun 2014 tentang Pengelolaan Barang Milik Negara/Daerah, yang dimaksud dengan BMN merupakan barang yang didapatkan atas beban APBN atau didapatkan secara sah. Aset tetap merupakan salah satu BMN yang dikuasai oleh setiap satuan kerja pemerintah. Aset tetap berperan besar untuk mendukung kegiatan operasional satuan kerja dan dapat digunakan secara umum oleh masyarakat. Aset tetap yang biasanya dikuasai oleh satuan kerja adalah tanah, gedung kantor, bangunan serba guna, serta peralatan dan mesin baik yang digunakan langsung oleh pegawai ataupun sebagai pelayanan kepada masyarakat.

Lain hal dengan aset lain yang dimiliki satuan kerja, aset tetap memiliki masa manfaat yang panjang, sehingga diperlukan biaya untuk pemeliharaan agar aset tetap dapat terus dipakai. Pemeliharaan secara periodik dilakukan sampai dengan masa manfaat dari aset tetap telah habis atau dilakukan penghentian penggunaan. Biaya tersebut akan dianggap sebagai beban pemeliharaan yang akan membebani belanja APBN. Selama masa manfaat masih berjalan, ada kemungkinan untuk terjadi kerusakan, telah ketinggalan jaman, tidak lagi sesuai dengan kebutuhan masa kini, atau hilang. Oleh karena itu, apabila aset tetap tidak lagi memberikan utilitas sebesar seharusnya atau biaya yang dikeluarkan lebih besar, maka perlu dilakukan penggantian aset tetap.

Perencanaan pengadaan aset tetap yang baru dilakukan ketika penganggaran APBN. Setelah anggaran telah tersedia pada tahun anggaran berjalan, entitas dapat melakukan pembelian aset tetap yang baru. Selanjutnya aset tetap dilakukan penatausahaan akuntansi sesuai dengan kebijakan yang berlaku. Penatausahaan akuntansi tidak hanya dilakukan terhadap aset tetap yang baru, namun menyeluruh terhadap aset yang dimiliki oleh entitas. Penatausahaan aset tetap yang baik juga harus menghasilkan laporan akuntansi yang akuntabel. Nilai BMN harus disajikan secara kredibel untuk mencerminkan keadaan dari entitas akuntansi tersebut.

Penerapan basis akrual telah dimulai dari tahun anggaran 2015, namun tetap ada beberapa laporan keuangan pemerintah yang mendapatkan opini BPK yang tidak memuaskan. Oleh karena itu, penelitian 
partial terhadap akuntansi aset tetap ini dilakukan dengan harapan mengetahui faktor penghalang mendapat opini wajar tanpa pengecualian (WTP) dari BPK. Rumusan masalah yang menjadi pembahasan dalam penelitian ini adalah meninjau bagaimana implementasi kebijakan akuntansi aset tetap antara lain tentang klasifikasi, pengakuan, pengukuran, penyusutan, serta penyajian dan pengungkapan aset tetap pada satuan kerja pemerintah. Tujuan yang ingin dicapai dari penilitian ini adalah mengetahui keakuratan implementasi kebijakan akuntansi aset tetap antara lain tentang klasifikasi, pengakuan, pengukuran, penyusutan, serta penyajian dan pengungkapan aset tetap pada satuan kerja pemerintah.

Ruang lingkup dari pembahasan penelitian ini terbatas pada penerapan akuntansi aset tetap pada satuan kerja pemerinah. Satuan kerja pemerintah yang dijadikan objek penelitian adalah kantor daerah dari salah satu kementerian yang berada di Provinsi Lampung. Objek penelitian selanjutnya akan disebut sebagai "Satker" dalam penelitian ini. Pembahasan penerapan akuntansi aset tetap yang dimaksud meliputi klasifikasi, pengakuan, pengukuran, penyusutan, sampai dengan penyajian dan pengungkapan aset tetap. Data yang digunakan untuk penelitian adalah hal yang berhubungan dengan pengelolaan aset tetap pada satuan kerja pemerintah pada tahun 2019.

\section{LANDASAN TEORI}

Berdasarkan Peraturan Pemerintah Nomor 71 tahun 2010 tentang Standar Akuntansi Pemerintah, pemerintah diharuskan untuk mengubah standar akuntansi yang sebelumnya berbasis kas menjadi berbasis akrual. Standar Akuntansi Pemerintahan selanjutnya akan diatur lebih lanjut dalam PSAP. Salah satu yang diatur adalah akuntansi aset tetap. Menurut Pernyataan Standar Akuntansi Pemerintah 07 tentang Akuntansi Aset Tetap, definisi dari aset tetap adalah aset yang memiliki wujud serta memiliki masa guna lebih dari dua belas bulan dalam rangka usaha pemerintah dan kepentingan publik.

\section{Klasifikasi Akuntansi Aset Tetap Pemerintah}

Untuk memudahkan dalam penataan informasi, maka aset-aset dilakukan klasifikasi berdasarkan kesamaan dalam fungsi atau sifat dalam aktivitas operasi entitas. Dalam Buletin Teknis Nomor 15 tentang Akuntansi Aset Tetap Berbasis Akrual, terdapat 6 klasifikasi untuk aset tetap, yaitu tanah; peralatan dan mesin; gedung dan bangunan; jalan, irigasi, dan jaringan; aset tetap lainnya; serta konstruksi dalam pengerjaan.

\section{Tanah}

Menurut Bultek 15, aset tetap berupa tanah merupakan tanah yang dipakai untuk aktivitas usaha pemerintah dan dalam keadaan layak pakai. Tanah dapat dibagi lagi menjadi dua kelompok menurut sifat dan namanya menjadi tanah untuk gedung dan bangunan dan tanah untuk bukan gedung 


\section{DA}

Vol. 6, No. 1, Oktober 2021

dan bangunan, seperti untuk jalan, irigasi, jaringan, ladang, lahan hutan, lahan pertanian, dan lahan perkebunan.

\section{Peralatan dan Mesin}

Menurut Bultek 15, aset tetap berupa peralatan dan mesin merupakan mesin dan kendaraan bermotor, peralatan elektronik, inventaris kantor, dan peralatan lainnya yang memiliki nilai penting dan masa gunanya diatas dua belas bulan dan dalam keadaan dapat digunakan. Peralatan dan mesin dapat dikelompokkan lebih lanjut menurut jenisnya, seperti komputer, peralatan kantor, peralatan komunikasi, peralatan berat, peralatan olah raga, peralatan pengangkut, peralatan dokter, peralatan montir, dan patok.

\section{Gedung dan Bangunan}

Menurut Bultek 15, aset tetap yang masuk dalam gedung dan bangunan merupakan gedung dan bangunan yang dibeli, dipakai pada aktivitas usaha pemerintah, dan dalam kondisi layak pakai. Gedung dan bangunan dapat dikelompokkan menurut jenisnya seperti perkantoran, tempat ibadah, perumahan kedinasan, menara, gudang, benda sejarah, dan permuseuman. Gedung dan bangunan tersebut merupakan selain tanah yang diminta untuk pembuatan gedung, struktur, atau bangunan yang masih dalam pembangunan.

\section{Jalan, Irigasi, dan Jaringan}

Menurut Bultek 15, aset tetap yang masuk dalam jalan, irigasi, dan jaringan adalah jalan, irigasi, dan jaringan pipa yang didirikan pemerintah dan dikuasai pemerintah dalam keadaan layak pakai. Jalan, irigasi, dan jaringan dapat diklasifikasikan lebih lanjut sesuai dengan kebutuhan entitas pelaporan, seperti jalan, waduk, jembatan, saluran irigasi, instalasi pembangkit listrik, pemasangan penyaluran air, pemasangan penyaluran listrik, pemasangan penyaluran gas, saluran transmisi gas, jaringan telepon, dan lain-lain. Jalan, irigasi, dan jaringan tersebut tidak termasuk tanah yang diperoleh untuk pembangunan gedung dan bangunan yang ada di atasnya. Klasifikasi yang tepat akan memudahkan untuk menetapkan kebijakan pemeliharaan ataupun penyusutan dari aset bersangkutan.

\section{Aset Tetap Lainnya}

Menurut Bultek 15, aset tetap yang masuk aset tetap lainnya merupakan aset tetap yang dibeli dan digunakan oleh pemerintah untuk kegiatan usaha yang tidak dapat diklasifikasikan sebagai aset tetap, aset tetap tanah, peralatan dan mesin, bangunan dan aset tetap gedung, jalan, irigasi, dan aset tetap jaringan, serta dalam keadaan layak pakai. Aset yang tergolong aset tetap lainnya antara lain koleksi perpustakaan/buku dan bukan buku, barang seni/budaya/olahraga, dan makhluk hidup seperti hewan, ikan, dan tumbuhan.

\section{Konstruksi Dalam Pembangunan}

Menurut Bultek 15, konstruksi dalam pembangunan yang termasuk dalam aset tetap adalah aset-aset tetap yang dalam proses 
mendapatkannya dan/atau pembangunan memerlukan suatu kurun waktu tertentu dan belum selesai. Hal ini harus dilaksanakan oleh entitas dalam membangun aset tetap yang akan dipakai untuk terselenggaranya operasional pemerintah dan/atau bentuk layanan publik dengan jangka waktu tertentu, baik dilakukan melalui swakelola maupun oleh pihak ketiga.

\section{Pengakuan Akuntansi Aset Tetap Pemerintah}

Menurut Peraturan Pemerintah Nomor 71 tahun 2010 tentang Standar Akuntansi Pemerintah, setiap entitas pemerintah diharuskan untuk menggunakan basis akrual. Pengakuan berbasis akrual maknanya adalah pengakuan yang didasarkan atas munculnya hak dan kewajiban yang memengaruhi entitas, tidak hanya berdasarkan adanya arus kas. Aset tetap dapat diakui ketika adanya manfaat ekonomi masa depan yang didapatkan dan nilai aset terukur andal. Pengakuan aset tetap yang handal dilakukan ketika adanya pemindahan hak kepemilikannya dan/atau penguasaan dari aset yang dimaksud. Apabila aset tetap didapat melalui hibah/donasi, maka aset diakui ketika hak miliknya sudah pindah, sedangkan aset tetap yang didapat dari sitaan/rampasan diakui pada waktu terdapat putusan instansi yang mempunyai kuasa hukum tetap.

Menurut PSAP 07, suatu aset yang dimiliki oleh entitas agar dapat diakui menjadi aset tetap harus memiliki beberapa kriteria. Kriteria yang dibutuhkan antara lain aset harus memiliki bentuk yang dapat diraba, masa guna diatas dua belas bulan, biaya perolehan yang terukur andal, tidak bermaksud dipasarkan dalam operasi normal entitas, dan diperoleh atau dibangun agar dapat digunakan. Kriteria tersebut harus dipenuhi tanpa ada terkecuali agar dapat diakui sebagai aset tetap.

Dalam Bultek Nomor 15, pengakuan aset tetap juga harus memperhatikan ketentuan nilai satuan minimum kapitalisasi aset tetap yang berlaku. Pada tahun anggaran 2019, ketentuan nilai minimum kapitalisasi berupa aset tetap diatur dalam Peraturan Menteri Keuangan Nomor 181/PMK.06/2016 tentang Penatausahaan Barang Milik Negara. Dalam peraturan tersebut, kapitalisasi aset tetap adalah pembelian aset tetap sampai dapat digunakan dan/atau peningkatan kapasitas/efisiensi dan/atau penambahan umur pakai, kecuali aset tetap lainnya seperti hewan, ikan, dan tumbuhan. Pengaturan nilai satuan minimum kapitalisasi adalah sebagai berikut:

1. Klasifikasi peralatan dan mesin, nilai minimal kapitalisasi per satuan adalah sama atau diatas Rp1.000.000,00;

2. Klasifikasi gedung dan bangunan, nilai minimal kapitalisasi untuk per satuan adalah setara atau diatas Rp25.000.000,00; dan

3. Klasifikasi aset tetap berupa tanah, jalan, irigasi dan jaringan, konstruksi dalam pengerjaan, dan aset tetap lainnya, tidak diperlukan nilai minimal kapitalisasi.

Berdasarkan Peraturan Menteri Keuangan Nomor 224/PMK.05/2016

tentang Perubahan atas Peraturan Menteri Keuangan Nomor 


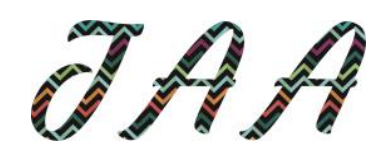

Vol. 6, No. 1, Oktober 2021

219/PMK.05/2013 tentang Kebijakan Akuntansi Pemerintah Pusat, pengakuan aset tetap dapat dikelompokkan lebih lanjut menurut jenis transaksinya, antara lain sebagai berikut.

1. Akuisisi, merupakan transaksi untuk memperoleh real properti, pabrik dan peralatan sebelum aset tersebut dalam keadaan dapat digunakan.

2. Pengembangan, merupakan transaksi yang meningkatkan nilai aset tetap, sehingga memperpanjang masa pakai, meningkatkan efisiensi, meningkatkan kapasitas produksi, kualitas dan kinerja produksi, dan/atau mengurangi biaya operasional.

3. Pengurangan, merupakan transaksi menurunkan nilai aset tetap yang terjadi akibat penurunan kuantitas/nilai aset tetap atau karena penyusutan.

4. Pengakhiran dan pelepasan, merupakan transaksi yang berhenti digunakan atau secara permanen mengakhiri aset tetap.

\section{Pengukuran Akuntansi Aset Tetap Pemerintah}

Berdasarkan Peraturan Menteri Keuangan Nomor 224/PMK.05/2016 tentang Perubahan atas Peraturan Menteri Keuangan Nomor 219/PMK.05/2013 tentang Kebijakan Akuntansi Pemerintah Pusat, pengukuran aset tetap dinilai dengan biaya perolehannya untuk mendapatkan aset tetap sampai dalam kondisi siap digunakan. Tetapi bila biaya perolehan aset tidak terdapat nilai maupun non-identifikasi, nilainya berdasar nilai wajar aset saat pembelian. Biaya pembelian dan konstruksi mengacu pada jumlah kas/setara kas atau nilai wajar dari pertimbangan lain yang dibayarkan pada saat pembelian dan konstruksi sampai aset layak digunakan. Adapun nilai wajar merupakan nilai penukaran aset maupun pengentasan kewajiban antar pihak yang memiliki pemahaman dan tekad dalam hal transaksi wajar. Nilai wajar dipakai untuk melakukan pencatatan aset tetap yang didapat dari hibah/donasi maupun sitaan/rampasan yang tidak diketahui nilai perolehannya, serta aset yang diperoleh dari bonus pembelian.

Dalam melakukan pengukuran aset tetap, ada beberapa hal yang perlu diperhatikan. Hal yang perlu diperhatikan antara lain sebagai berikut.

\section{Komponen Biaya Perolehan}

Hal yang menjadi bagian dari biaya perolehan terbagi atas harga pembelian atau biaya konstruksi (mencakup pajak pembelian dan bea impor, dengan diskon dan/atau rabat jika ada sebagai pengurang) dan cost lain yang langsung memiliki hubungan dengan aset sampai dengan aset dapat dipakai untuk penggunaan yang diinginkan. Beberapa contoh biaya yang memiliki hubungan langsung terhadap aset adalah biaya pengiriman, biaya persiapan tempat, biaya pemasangan, biaya konstruksi, biaya jasa, dan biaya pengujian aset sebelum siap digunakan.

\section{Pengeluaran setelah Tanggal Perolehan}


Selain pada awal perolehan, nilai aset dapat mengalami perubahan akibat adanya pengeluaran tertentu. Pengeluaran tertentu ini berpengaruh pada bertambah masa manfaat aset, kualitas aset, kapasitas aset dan volume aset sehingga perlu dilakukan penambahan nilai asetnya. Namun hal ini dilakukan hanya ketika pengeluaran itu telah memenuhi minimum nilai kapitalisasi dari aset tetap yang berlaku keuntungan, maka biaya perolehan dari aset ini ditulis senilai nilai tercatat (carrying amount) dari aset yang diserahkan. Apabila ada indikasi dari nilai wajar aset yang diterima perlu dilakukan perbaikan untuk mencapai kondisi yang diharapkan, maka biaya perolehan dari aset ini ditulis sebesar nilai aset yang dilepas dan biaya yang dikeluarkan untuk perbaikan aset tersebut.

\section{Pertukaran}

Aset tetap yang didapat dari transaksi pertukaran aset, maka biaya perolehan dari aset tersebut berupa nilai wajar dari aset yang diserahkan dan penyesuaian jumlah kas/setara kas lainnya yang dikeluarkan. Apabila aset yang diterima memiliki manfaat dan nilai wajar yang setara serta tidak ada indikasi kerugian.

\section{Penyusutan Aset Tetap Pemerintah}

Seiring dengan masa manfaat, suatu aset tetap yang digunakan oleh suatu entitas akan mengalami pengurangan manfaat ekonomi yang melekat. Pengurangan manfaat ekonomi yang telah lalu perlu dilakukan pencatatan sehingga diperlukan penyesuaian nilai aset tetap atau disebut dengan penyusutan. Menurut Peraturan Menteri Keuangan Nomor 65/PMK.06/2017 tentang Penyusutan Barang Milik Negara Berupa Aset Tetap pada Entitas Pemerintah Pusat, penyusutan adalah alokasi sistematis atas nilai suatu aset tetap yang dapat disusutkan selama masa manfaat aset tersebut. Nilai penyusutan suatu aset tetap kemudian menjadi pengurang nilai tercatat dari aset tetap tersebut dalam neraca. Tujuan dilakukannya penyusutan aset tetap adalah sebagai berikut.

1. Menampilkan sajian nilai aset tetap berdasar guna ekonomi aset secara wajar pada laporan keuangan pemerintah pusat;

2. Menilik potensi aset tetap dengan meramalkan sisa guna manfaat yang dapat digunakan lagi kedepannya; dan

3. Memberikan pendekatan dalam menentukan anggaran untuk belanja pemeliharaan atau belanja modal untuk penggantian maupun menambah aset tetap.

Beberapa hal yang perlu diketahui dalam melakukan penghitungan nilai penyusutan aset tetap adalah nilai yang dapat disusutkan dan masa manfaat aset dari aset tetap yang ingin dihitung. Penentuan masa manfaat suatu aset dilakukan saat awal perolehan aset dengan mempertimbangkan unsur-unsur seperti ekspektasi pemakaian aset oleh entitas, ekspektasi tingkat keausan/kerusakan aset, keausan teknis yang mungkin terjadi, dan ketentuan hukum atau batasan atas pemakaian aset (contohnya tanggal kadaluarsa). Nilai yang dijadikan acuan penghitungan penyusutan adalah 


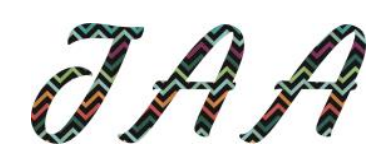

Vol. 6, No. 1, Oktober 2021

nilai ketika perolehan awal dan nilai tambahan ketika ada pengeluaran setelah perolehan.

Metode penyusutan aset tetap yang diterapkan oleh pemerintah adalah metode garis lurus. Metode garis lurus dipilih dengan alasan perhitungannya mudah, sehingga ketika diterapkan tidak merintangi entitas akuntansi ketika menghitung dan menganalisis. Rumusan perhitungan dengan metode garis lurus ditunjukkan oleh gambar berikut:

$\begin{gathered}\text { Penyusutan Per } \\ \text { Periode }\end{gathered}$
.

Formula Metode Garis Lurus

Sumber: PMK 224/PMK.05/2016

Adapun aset tetap yang tidak dilakukan penyusutan antara lain tanah, konstruksi dalam pembangunan, serta aset tetap yang dinyatakan hilang berdasarkan dokumen sumber yang sah dan aset tetap dalam keadaan rusak berat dan/atau usang yang telah dilakukan pengusulan penghentian penggunaan.

\section{Penyajian dan Pengungkapan Aset Tetap Pemerintah}

Berdasarkan Peraturan Menteri Keuangan Nomor 224/PMK.05/2016, aset tetap disajikan dengan menunjukkan biaya perolehan aset tetap dikurangi akumulasi penyusutan. Penyajian aset tetap pada pos-pos neraca sesuai dengan klasifikasi aset tetap yang ada. Penyajian aset tetap pada neraca diilustrasikan oleh gambar berikut:

\begin{tabular}{|c|c|}
\hline URAIAN & JUМLАН \\
\hline \multicolumn{2}{|l|}{ ASET } \\
\hline \multicolumn{2}{|l|}{ ASET LANCAR } \\
\hline & \\
\hline \multicolumn{2}{|l|}{ ASET TETAP } \\
\hline Tanah & $\mathrm{xxx}$ \\
\hline Peralatan dan Mesin & $\mathrm{xxx}$ \\
\hline Gedung dan Bangunan & $\mathrm{xxx}$ \\
\hline Jalan Irigasi dan Jaringan & $\mathrm{xxx}$ \\
\hline Konstruksi dalam Pengerjaan & $\mathrm{xxx}$ \\
\hline Aset Tetap Lainnya & $\mathrm{xxx}$ \\
\hline Akumulasi Penyusutan Aset Tetap & $(\mathrm{xxx})$ \\
\hline \multicolumn{2}{|l|}{ ASET LAINNYA } \\
\hline Aset Lain-lain & $\mathrm{xxx}$ \\
\hline Akumulasi Penyusutan/Amortisasi Aset Laimnya & $(\mathrm{xxx})$ \\
\hline \multicolumn{2}{|l|}{ KEWAJIBAN } \\
\hline EKUTTAS & \\
\hline
\end{tabular}


Neraca Laporan Keuangan

Sumber: PMK 224/PMK.05/2016

Pengungkapan dilakukan untuk memberikan penjelasan yang cukup dan mewakili keadaan yang sebenarnya yang ada di entitas selama periode. Informasi terbatas yang telah disajikan pada laporan keuangan pemerintah selanjutnya diungkapkan lebih lanjut untuk masing-masing posnya pada catatan atas laporan keuangan (CaLK). Beberapa hal yang wajib untuk dilakukan pengungkapan pada masing-masing aset tetap adalah sebagai berikut.

1. Standar penilaian yang diperlukan sebagai penentuan nilai buku;

2. Tabel rekonsiliasi nilai buku dalam pembukaan dan penutupan periode menampilkan kenaikan, pengeluaran, akumulasi penyusutan dan pergantian nilai, serta aset tetap lainnya;

3. Informasi penyusutan, termasuk nilai penyusutan, metode penyusutan yang dipakai, masa guna atau harga susut yang dipakai, dan total nilai buku dan penghimpunan penyusutan pada pembukaan dan penutupan periode;

4. Info terkait dengan ditukarnya aset tetap, termasuk pihak pertukaran, jenis dan nilai dari aset tetap yang diterima, jenis dan nilai dari aset tetap yang diserahkan, dan jumlah subsidi yang melebihi pertukaran aset tetap; serta

5. Hal untuk mengungkap, antara lain keberadaan dan pembatasan kepemilikan aset tetap, kebijakan akuntansi kapitalisasi terkait aset tetap, jumlah aset tetap dalam penyelesaian, dan jumlah perikatan dalam perolehan aset tetap.

\section{METODE PENELITIAN}

Metode yang dipakai sebagai tempat mengumpulkan data yang diperlukan untuk penelitian adalah untuk data primer melalui wawancara dan untuk data sekunder melalui dokumen. Pertama, peneliti memberikan pertanyaan seputar masalah terkait akuntansi aset tetap yang telah dilakukan oleh Satker. Wawancara dilakukan melalui virtual sebagai bentuk ketaatan protokol kesehatan yang berlaku. Kedua, peneliti menelaah dokumen-dokumen berupa Laporan Keuangan Tahun Anggaran 2019 yang telah dibuat oleh Satker serta dokumen pendukung lain yang memiliki kekuatan hukum tetap.

\section{Klasifikasi Aset Tetap pada Satker}

Menurut Neraca Satker per 31 Desember 2019, aset tetap diklasifikasikan menjadi sebagai berikut:

\section{Tanah}

Tanah yang dimiliki oleh Satker yang dilaporkan dengan kode akun 131111 dalam neraca per 31 Desember 2019 sebesar Rp6.990.718.000,00. 


\section{$D A$}

Vol. 6, No. 1, Oktober 2021

Tanah yang dimiliki merupakan tanah yang digunakan untuk bangunan kantor pemerintahan seluas $3.074 \mathrm{~m} 2$.

\section{Peralatan dan Mesin}

Peralatan dan mesin yang dimiliki oleh Satker yang dilaporkan dengan kode akun 132111 dalam neraca per 31 Desember 2019 sebesar Rp3.703.447.436,00. Rincian kelompok peralatan dan mesin yang berada di Satker dapat dilihat dalam laporan barang pengguna intrakomptabel yang menjadi lampiran dalam karya tulis tingkat akhir ini. Beberapa kelompok barang peralatan dan mesin yang ada antara lain minibus, sepeda motor, mesin fotokopi, lemari, CCTV, meja dan kursi, Air Conditioner, dan lain-lain.

\section{Gedung dan Bangunan}

Gedung dan Bangunan yang dimiliki oleh Satker yang dilaporkan dengan kode akun 133111 dalam neraca per 31 Desember 2019 sebesar Rp5.635.937.000,00. Rincian kelompok gedung dan bangunan yang berada di Satker dapat dilihat dalam laporan barang pengguna intrakomptabel yang menjadi lampiran dalam karya tulis tingkat akhir ini. Beberapa kelompok barang gedung dan bangunan yang ada antara lain gedung kantor, gedung tempat ibadah, gedung pos jaga, tempat parkir, dan rumah negara.

\section{Jalan, Irigasi, dan Jaringan}

Jalan, irigasi, dan jaringan yang dimiliki oleh Satker yang dilaporkan dengan kode akun 134113 dalam neraca per 31 Desember 2019 sebesar Rp16.690.820,00. Rincian kelompok jalan, irigasi, dan jaringan yang berada di Satker dapat dilihat dalam laporan barang pengguna intrakomptabel yang menjadi lampiran dalam karya tulis tingkat akhir ini. Kelompok barang jalan, irigasi, dan jaringan hanya ada jaringan berupa jaringan distribusi tegangan listrik.

\section{Aset Tetap Lainnya}

Aset tetap lainnya tidak dimiliki oleh Satker sehingga dilaporkan dalam neraca per 31 Desember 2019 sebesar Rp0,00.

\section{Konstruksi Dalam Pembangunan}

Konstruksi dalam pembangunan tidak dimiliki oleh Satker sehingga dilaporkan dalam neraca per 31 Desember 2019 sebesar Rp0,00.

\section{Pengakuan Aset Tetap pada Satker}

Menurut CaLK yang terdapat pada Satker pada tahun anggaran 2019, suatu aset dapat diakui sebagai aset tetap apabila telah memenuhi nilai satuan minimum kapasitas. Nilai satuan minimum kapasitas diatur sebagai berikut.

1. Nilai sama atau diatas Rp1.000.000,00 untuk per satuan peralatan dan mesin;

2. Nilai sama atau diatas Rp25.000.000,00 untuk gedung dan bangunan;

3. Pengeluaran selain dalam batas nilai minimal kapasitas tersebut poin satu dan dua, dibutuhkan untuk biaya kecuali pengeluaran untuk 
tanah, jalan/irigasi/jaringan, dan aset tetap lainnya berupa barang perpustakaan dan barang seni.

\section{Pengukuran Aset Tetap pada Satker}

Satker yang digunakan sebagai dasar pengukuran aset tetap dalam laporan keuangan adalah memakai nilai perolehan. Aset dicatat sebesar jumlah kas/setara kas yang dikeluarkan ataupun nilai wajar lain yang diberikan untuk memperoleh aset tersebut. Pengukuran ini dilakukan dengan memakai mata uang rupiah, apabila dilakukan dengan valuta asing maka perlu dikonversi terlebih dahulu ke mata uang rupiah.

\section{Penyusutan Aset Tetap pada Satker}

Menurut catatan atas laporan keuangan Satker tahun anggaran 2019, penyusutan aset tetap adalah penyesuaian nilai sehubungan dengan penurunan kapasitas dan manfaat dari suatu aset tetap. Adapun beberapa aset tetap yang tidak dilakukan penyusutan adalah tanah, konstruksi dalam pengerjaan, dan aset tetap yang hilang bersumber dari dokumen sumber yang diakui maupun pada keadaan rusak parah dan/atau usang yang telah diajukan kepada pengelola barang untuk dihapus.

Perhitungan penyusutan dilaksanakan pada penutupan semester tanpa menghitung nilai sisa dengan memakai metode garis lurus.

Penyusutan dengan metode garis lurus adalah pengalokasian nilai yang dapat disusutkan secara rata-rata pada tiap semester selama masa manfaat aset tetap tersebut. Masa manfaat ditentukan dengan berpedoman pada Peraturan Menteri Keuangan Nomor 59/PMK.06/2013 tentang Tabel Masa Manfaat dalam Rangka Penyusutan Barang Milik Negara Berupa Aset Tetap pada Entitas Pemerintah Pusat. Penggolongan masa manfaat aset tetap secara umum dilakukan sesuai dengan tabel berikut.

\begin{tabular}{|l|c|}
\hline \multicolumn{1}{|c|}{ Kelompok Aset Tetap } & Masa Manfaat \\
\hline Peralatan dan Mesin & 2 s.d. 20 Tahun \\
\hline Gedung dan Bangunan & 10 s.d. 50 Tahun \\
\hline Jalan, Irigasi, dan Jaringan & 5 s.d. 40 Tahun \\
\hline Aset Tetap Lainnya & 4 Tahun \\
\hline
\end{tabular}

Penggolongan Tabel Masa Manfaat Aset Tetap

Sumber: PMK Nomor 59/PMK.06/2013

Saldo akumulasi penyusutan aset tetap per 31 Desember 2019 sebesar Rp3.294.409.527,00 dengan rincian yang terdapat pada tabel berikut.

\begin{tabular}{|l|lr|}
\hline \multicolumn{1}{|c|}{ Kelompok Aset Tetap } & \multicolumn{2}{c|}{ Akumulasi Penysuutan } \\
\hline Peralatan dan Mesin & $\mathrm{Rp}$ & $(2.962 .640 .604)$ \\
\hline Gedung dan Bangunan & $\mathrm{Rp}$ & $(327.503 .721)$ \\
\hline Jalan, Irigasi, dan Jaringan & $\mathrm{Rp}$ & $(4.265 .202)$ \\
\hline Aset Tetap Lainnya & $\mathrm{Rp}$ & - \\
\hline \multicolumn{1}{|c|}{ Jumlah } & Rp & $\mathbf{( 3 . 2 9 4 . 4 0 9 . 5 2 7 )}$ \\
\hline
\end{tabular}




\section{$\partial A A$}

Vol. 6, No. 1, Oktober 2021

Rincian Akumulasi Penyusutan Aset Tetap Tahun 2019

Sumber: CaLK Satker

\section{Penyajian dan Pengungkapan Aset Tetap pada Satker}

Satker melakukan penyajian aset tetap dalam neraca laporan keuangan dengan rincian terlihat pada table berikut.

\begin{tabular}{|c|c|c|}
\hline \multirow{2}{*}{ URAIAN } & \multicolumn{2}{|c|}{ JUMLAH } \\
\hline & 2019 & 2018 \\
\hline \multicolumn{3}{|l|}{ ASET } \\
\hline \multicolumn{3}{|l|}{ ASET LANCAR } \\
\hline \multicolumn{3}{|l|}{ ……................ } \\
\hline & & \\
\hline \multicolumn{3}{|l|}{ ASET TETAP } \\
\hline Tanah & Rp 6.990.718.000 & Rp 6.990 .718 .000 \\
\hline Peralatan dan Mesin & Rp 3.703 .447 .436 & Rp 2.858 .066 .823 \\
\hline Gedung dan Bangunan & Rp 5.635.937.000 & $\operatorname{Rp} 5.956 .724 .000$ \\
\hline Jalan, Irigasi dan Jaringan & $\begin{array}{ll}\mathrm{Rp} & 16.690 .820 \\
\end{array}$ & 16.690 .820 \\
\hline Konstruksi dalam Pengerjaan & $\mathrm{Rp}$ & $\mathrm{Rp}$ \\
\hline Aset Tetap Lainnya & $\mathrm{Rp}$ & $\mathrm{Rp}$ \\
\hline Akumulasi Penyusutan Aset Tetap & $\operatorname{Rp}(3.294 .409 .527)$ & $\operatorname{Rp}(2.861 .023 .770)$ \\
\hline \multicolumn{3}{|l|}{ ASET LAINNYA } \\
\hline Aset Lain-lain & Rp $\quad 332.924 .122$ & Rp $\quad 337.498 .622$ \\
\hline $\begin{array}{l}\text { Akumulasi Penyusutan /Amortisasi } \\
\text { Aset Lainnya }\end{array}$ & $\mathrm{Rp} \quad(332.924 .112)$ & $\operatorname{Rp} \quad(337.498 .622)$ \\
\hline \multicolumn{3}{|l|}{ KEWAJIBAN } \\
\hline EKUITAS & & \\
\hline
\end{tabular}

Sumber: Diolah dari Neraca Laporan Keuangan

Satker melakukan pengungkapan aset tetap pada catatan atas laporan keuangan dengan menjelaskan perubahan saldo awal periode dengan akhir periode pada tiap pos-pos aset tetap dikarenakan adanya mutasi tambah dan kurang yang terjadi selama tahun anggaran berjalan serta nilai buku dari aset tersebut apabila terjadi penyusutan. Penjelasan tentang perubahan pada tiap pos-pos aset tetap sebagai berikut:

\section{Tanah}

Tidak ada perubahan saldo tanah dikarenakan tidak terjadi mutasi selama tahun anggaran 2019. Jadi, saldo per 31 Desember 2019 adalah sebesar Rp6.990.718.000,00.

\section{Peralatan dan Mesin}

Ada perubahan saldo peralatan dan mesin dikarenakan terjadi mutasi tambah sebesar Rp259.291.708,00 dan mutasi kurang sebesar Rp330.000,00 selama tahun anggaran 2019. Mutasi tambah berasal dari transaksi pembelian, transfer masuk, dan reklasifikasi masuk, sedangkan 
mutasi keluar berasal dari reklasifikasi keluar. Jadi, saldo per 31 Desember 2019 adalah sebesar Rp3.117.028.531,00. Akumulasi penyusutan sampai dengan 31 Desember 2019 sebesar Rp2.962.640.604,00, kemudian nilai buku dari peralatan dan mesin per 31 Desember 2019 sebesar Rp6.079.669.135,00.

\section{Gedung dan Bangunan}

Tidak ada perubahan saldo gedung dan bangunan dikarenakan tidak terjadi mutasi selama tahun anggaran 2019. Jadi, saldo per 31 Desember 2019 adalah sebesar Rp3.956.724.000,00. Akumulasi penyusutan sampai dengan 31 Desember 2019 sebesar Rp327.503.721,00, kemudian nilai buku dari jalan, irigasi, dan jaringan per 31 Desember 2019 sebesar Rp5.629.220.279,00.

\section{Jalan, Irigasi, dan Jaringan}

Tidak ada perubahan saldo jalan, irigasi, dan jaringan dikarenakan tidak terjadi mutasi selama tahun anggaran 2019.Jadi, saldo per 31 Desember 2019 adalah sebesar Rp16.690.820,00. Akumulasi penyusutan sampai dengan 31 Desember 2019 sebesar Rp4.265.202,00, kemudian nilai buku dari jalan, irigasi, dan jaringan per 31 Desember 2019 sebesar Rp12.425.618,00.

\section{Aset Tetap Lainnya}

Satker tidak memiliki aset berupa aset tetap lainnya.

\section{Konstruksi Dalam Pembangunan}

Satker tidak memiliki aset berupa konstruksi dalam pembangunan.

\section{HASIL PENELITIAN DAN PEMBAHASAN}

\section{Klasifikasi Aset Tetap Pada Satker}

Menurut Buletin Teknis Nomor 15 tentang Akuntansi Aset Tetap Berbasis Akrual, terdapat enam klasifikasi untuk aset tetap, yaitu tanah, peralatan dan mesin, gedung dan bangunan, jalan, irigasi, dan jaringan, aset tetap lainnya, serta konstruksi dalam pengerjaan. Klasifikasi dilakukan berdasarkan kesamaan dalam fungsi atau sifat dalam kegiatan operasional satuan kerja.

Klasifikasi aset tetap pada Satker hanya terdiri dari 4 pos, yaitu tanah, peralatan dan mesin, gedung dan bangunan, serta jalan, irigasi, dan jaringan. Dengan nilai untuk tiap klasifikasi per 31 Desember 2019 adalah tanah sebesar Rp6.990.718.000,00, peralatan dan mesin sebesar Rp3.703.447.436,00, gedung dan bangunan sebesar Rp5.635.937.000,00, serta jalan, irigasi, dan jaringan sebesar Rp16.696.820,00. Menurut hasil wawancara, pengelompokkan aset tetap dilakukan berdasarkan dengan fungsi dan sifat aset tersebut.

Pos aset tetap berupa aset tetap lainnya dan konstruksi dalam pembangunan bernilai Rp0,00 dikarenakan Satker sampai dengan 31 Desember 2019 tidak memiliki aset yang dapat dikelompokkan ke dalam 


\section{DA}

Vol. 6, No. 1, Oktober 2021

pos tersebut. Gedung dan bangunan yang dimiliki Satker sudah mencukupi kebutuhan dan dalam keadaan yang baik, seperti gedung kantor yang selesai direnovasi pada tahun 2012. Umur masa manfaat yang masih muda sehingga tidak ada rencana untuk melakukan pembangunan konstruksi yang baru dalam tahun anggaran 2019.

Hasil penelitian adalah aset-aset tetap yang dimiliki oleh suatu Satker bermacam-macam dan memiliki jumlah yang cukup banyak sehingga perlu dilakukan pengelompokan. Satker telah melakukan pengklasifikasian aset tetap sesuai dengan kebijakan akuntansi yang berlaku. Kesesuaian klasifikasi aset tetap yang dilakukan selanjutnya dapat memudahkan dalam penatausahaan informasi seperti penyajian di neraca dan penghitungan penyusutan untuk aset tetap pada tiap pos-posnya.

\section{Pengakuan Aset Tetap Pada Satker}

Standar akuntansi untuk pemerintah yang berlaku saat ini mengharuskan penggunaan basis akrual. Pengakuan yang berbasis akrual dilakukan ketika telah munculnya hak dan kewajiban yang mempengaruhi entitas. Menurut PSAP 07, ada beberapa kriteria agar suatu aset dapat diakui menjadi aset tetap. Kriteria tersebut antara lain suatu aset harus berwujud, memiliki masa guna diatas satu tahun, biaya perolehan aset perlu diukur secara andal, dan aset diperoleh dengan maksud dipakai, bukan dipasarkan dalam operasi normal entitas. Selain kriteria tersebut, biaya perolehan suatu aset perlu mencapai atau melebihi dari nilai satuan minimum kapitalisasi aset yang telah ditentukan. Jadi, suatu aset dapat diakui sebagai aset tetap setelah munculnya hak dan kewajiban, seluruh kriteria tersebut telah terpenuhi, serta telah memenuhi nilai minimum kapitalisasi aset tetap.

Menurut CaLK Satker, pengakuan aset tetap dilakukan berdasarkan pada nilai satuan minimum kapasitas. Suatu aset dapat diakui sebagai aset tetap apabila biaya perolehan sama dengan atau melebihi dari nilai satuan minimum kapasitas. Nilai satuan minimum kapasitas ini diatur untuk peralatan dan mesin serta gedung dan bangungan, sedangkan untuk tanah, jalan/irigasi/jaringan, aset lainnya tidak ada nilai minimumnya. Selain itu, dari hasil wawancara didapatkan informasi bahwa suatu aset tetap mulai diakui ketika dilakukan perikatan kontrak dan sudah membebani APBN. Selanjutnya pencatatan dilakukan secara sistem melalui sistem aplikasi keuangan tingkat instansi (SAKTI).

Dalam penerapannya, pengakuan berbasis akrual terus menerus mengalami peningkatan ketepatan. Hal ini didukung pula dengan pencatatan yang dibantu dengan sistem, sehingga setiap kontrak yang telah menjadi beban APBN secara paralel akan berpengaruh pada pencatatan akuntansi. Di sisi lain, pengguna sistem harus memiliki pemahaman mengenai kriteria yang diperlukan untuk menjadi aset tetap agar tidak terjadi kesalahan pencatatan. 
Hasil penelitian menafsirkan bahwa Satker telah melakukan pengakuan aset tetap sesuai dengan kebijakan akuntansi berbasis akrual yang berlaku. Dimulai dari waktu pengakuan, kriteria aset tetap yang dibutuhkan, serta biaya perolehan yang dikeluarkan harus memenuhi nilai satuan minimum kapitalisasi yang berlaku. Meskipun ada beberapa hal yang menjadi temuan, seperti halnya perbedaan diksi dan tidak adanya dokumen tertulis. Perbedaan diksi yang dimaksud adalah penggunaan kapasitas untuk kapitalisasi, meskipun kata yang dipakai berbeda namun konteks yang ingin disampaikan/diatur merupakan hal yang sama, jadi tidak menjadi penghambat. Kemudian secara tertulis pada CaLK hanya disebutkan mengenai pengaturan nilai satuan minimum kapitalisasi, namun tidak dijelaskan mengenai waktu pengakuan dan kriteria aset tetap. Hal ini tidak perlu dijelaskan dalam CaLK mengingat kedua hal tersebut merupakan dasar dan info umum yang dimiliki oleh setiap pegawai, sehingga tidak perlu lagi diingatkan kembali dalam CaLK.

\section{Pengukuran Aset Tetap Pada Satker}

Berdasarkan PMK 224/PMK.05/2016 tentang Kebijakan Akuntansi Pemerintah Pusat, pengukuran aset tetap dilakukan berdasarkan biaya perolehan suatu aset sampai dalam keadaan siap dipakai. Biaya perolehan dapat berupa total kas/setara kas yang dibayar atau nilai wajar dari imbalan lain yang diberikan. Nilai wajar dipakai sebagai pencatatan aset tetap yang didapat dari hibah/donasi atau sitaan/rampasan yang asal usulnya tidak diketahui.

Menurut CaLK Satker, pelaksanaan pengukuran aset tetap dilakukan dengan menghitung biaya perolehan untuk menciptakan suatu aset tetap. Biaya perolehan merupakan total kas/setara kas yang dibayar kepada pihak ketiga atau nilai wajar imbalan lain yang diberikan dari orang lain. Pengukuran aset tetap melalui biaya perolehan tetap dilakukan sampai dengan aset tetap tersebut telah layak untuk digunakan.

Untuk aset tetap yang didapat dari pembelian, yang menjadi biaya perolehan antara lain harga pembelian aset tersebut beserta biaya-biaya tambahan yang dibutuhkan seperti biaya perjalanan dinas, biaya pemasangan, biaya ongkos kirim, dan biaya-biaya lain yang menunjang penciptaan aset baru tersebut. Kemudian, untuk aset tetap yang didapat dari hibah/donasi, sitaan/rampasan, serta aset yang diperoleh dari bonus pembelian, biaya perolehan diukur dengan nilai wajar dari aset ditambah dengan biaya-biaya yang diperlukan agar aset tersebut dapat siap dipakai, seperti biaya ongkos dan biaya perbaikan.

Sampai saat ini, Satker telah melakukan pengukuran aset tetap sesuai dengan kebijakan akuntansi yang berlaku. Dengan mengidentifikasi biaya-biaya apa saja yang menjadi nilai tambah untuk mengetahui biaya perolehan, maka dapat meningkatkan ketepatan pengukuran aset tetap tersebut. Pengukuran yang baik maka akan menunjukkan keadaan aset tetap yang mendekati sebenarnya dari sudut pandang akuntansi. 


\section{DA}

Vol. 6, No. 1, Oktober 2021

\section{Penyusutan Aset Tetap Pada Satker}

Menurut PMK 65/PMK.06/2017 tentang Penyusutan Barang Milik Negara Berupa Aset Tetap pada Entitas Pemerintah Pusat, penyusutan dilakukan pada aset tetap selama masih dapat disusutkan sampai dengan masa manfaat asetnya habis. Nilai penyusutan dapat dihitung menggunakan salah satu metode yang dinilai paling relevan. Nilai penyusutan selanjutnya disajikan dalam neraca yang akan menjadi pengurang nilai dari aset tetap. Salah satu tujuan dilakukan penghitungan penyusutan aset tetap adalah untuk menyajikan nilai aset tetap secara wajar dalam laporan keuangan pemerintah pusat.

Pada Satker juga melakukan penghitungan penyusutan sebagai bentuk kesesuaian nilai yang berhubungan pada penurunan kapasitas dan kegunaan dari suatu aset tetap. Nilai penyusutan pada tiap semester bernilai sama disebabkan penghitungan menggunakan metode garis lurus. Namun tidak setiap aset tetap dilakukan penyusutan, ada beberapa aset tetap yang tidak dilakukan penyusutan. Aset tetap yang dimaksud adalah tanah, konstruksi dalam pengerjaan, serta aset tetap yang dinyatakan hilang atau dalam kondisi rusak berat.

Nilai penyusutan sampai dengan akhir periode akan disajikan dalam laporan keuangan. Dengan adanya perhitungan nilai penyusutan yang tepat, maka nilai buku dapat diketahui secara realistis. Apabila nilai buku dari suatu aset tetap memiliki proporsi sangat kecil dibandingkan nilai perolehan, maka aset tersebut hampir mencapai akhir masa manfaat. Selanjutnya, entitas perlu mempersiapkan anggaran pembelian aset untuk menggantikan aset yang akan habis tersebut.

Dalam pelaksanaannya, Satker telah melakukan perhitungan penyusutan terhadap peralatan dan mesin serta gedung dan bangunan yang dimiliki. Perhitungan penyusutan aset tetap dilakukan dengan metode garis lurus, metode ini dipilih sebab perhitungannya lebih mudah dibandingkan metode yang lain. Jadi, Satker telah menerapkan kebijakan akuntansi aset tetap yang berlaku.

\section{Penyajian dan Pengungkapan Aset Tetap pada Satker}

Menurut PMK Nomor 224/PMK.05/2016, penyajian aset tetap dilakukan dengan menampilkan biaya perolehan aset tetap dan dikurangi dengan akumulasi penyusutan aset tetap. Pada Satker, aset tetap disajikan dalam neraca yang telah sesuai dengan peraturan tersebut. Penyajian aset tetap berupa tanah, peralatan dan mesin, gedung dan bangunan, serta jalan, irigasi, dan jaringan sebesar Rp16.346.793.256,00 dikurangi dengan akumulasi penyusutan aset tetap sebesar Rp3.294.409.527,00. Jadi, aset tetap yang dimiliki oleh Satker sebesar Rp13.052.383.729,00. Pada neraca tidak disajikan aset tetap berupa aset tetap lainnya serta konstruksi dalam pengerjaan karena Satker tidak memiliki aset tetap tersebut. 
Selain itu, laporan keuangan Satker telah mengungkapkan informasi tentang aset tetap. Beberapa informasi yang diungkapkan dalam CaLK Satker adalah sebagai berikut.

1. Standar penilaian yang digunakan Satker untuk menentukan nilai tercatat berdasarkan pengukuran menggunakan biaya perolehan, yaitu dengan nilai perolehan atau menggunakan nilai wajar.

2. Satker melakukan rekonsiliasi total pencatatan pada pembukaan dan penutupan periode yang menunjukkan pertambahan, pengurangan, himpunan penyusutan, serta mutasi aset tetap lainnya. Pengungkapan rekonsiliasi aset tetap ditampilkan dalam CaLK Satker.

\begin{tabular}{|c|c|c|c|c|c|}
\hline \multirow[b]{2}{*}{ Uraian } & \multicolumn{5}{|c|}{ Pos-Pos Aset Tetap } \\
\hline & Tanah & $\begin{array}{c}\text { Peralatan dan } \\
\text { Mesin }\end{array}$ & $\begin{array}{c}\text { Gedung dan } \\
\text { Bangunan }\end{array}$ & & $\begin{array}{l}\text { Irigasi, dan } \\
\text { aringan }\end{array}$ \\
\hline Saldo per 1 Januari 2019 & Rp 6.990 .718 .000 & Rp 2.858.066.823 & Rp 5.956.724.000 & $\mathbf{R p}_{\mathbf{p}}$ & 16.690 .820 \\
\hline Mutasi Tambah & $\mathrm{Rp}$ & $\begin{array}{ll}\mathrm{Rp} & 259.291 .708 \\
\end{array}$ & $\mathrm{Rp}$ & $\mathrm{Rp}$ & - \\
\hline Mutasi Kurang & $\mathrm{Rp}$ & 330.000 & $\mathrm{Rp}$ & $\mathrm{Rp}$ & 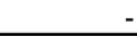 \\
\hline Saldo per 31 Desember 2019 & Rp 6.990.718.000 & Rp 3.117.028.531 & Rp 5.956.724.000 & $\mathbf{R p}_{\mathbf{p}}$ & 16.690 .820 \\
\hline $\begin{array}{l}\text { Akumulasi Penyusutan s.d. } 31 \\
\text { Desember } 2019\end{array}$ & & $\operatorname{Rp}(2.962 .640 .604)$ & $\operatorname{Rp} \quad 327.503 .721$ & $\mathrm{Rp}$ & 4.265 .202 \\
\hline Nilai Buku per 31 Desember 2019 & & Rp 6.079.669.135 & Rp 5.629.220.279 & $\mathbf{R}_{\mathbf{p}}$ & 12.425.618 \\
\hline
\end{tabular}

\section{Rekonsiliasi Aset Tetap Tahun 2019}

Sumber: Diolah dari CaLK Satker

3. Satker memberikan informasi penyusutan, meliputi hal berikut.

a. Metode penyusutan yang digunakan yaitu menggunakan metode garis lurus tanpa nilai sisa;

b. Masa manfaat yang digunakan telah mengacu pada PMK Nomor 59/PMK.06/2013 tentang Tabel Masa Manfaat dalam Rangka Penyusutan Barang Milik Negara Berupa Aset Tetap pada Entitas Pemerintah Pusat;

c. Satker mencatatkan akumulasi penyusutan aset tetap pada awal dan akhir periode sebesar Rp2.861.023.770,00 per 1 Januari 2019 dan Rp3.294.409.527,00 per 31 Desember 2019.

4. Hal-hal lain yang juga diungkapkan adalah kebijakan akuntansi mengenai kapitalisasi aset tetap sesuai dengan ketentuan pada PMK Nomor 181/PMK.06/2016 tentang Penatausahaan Barang Milik Negara.

Jadi hasil dari penelitian, Satker telah melakukan penyajian dan pengungkapan berdasarkan ketentuan pada peraturan yang berlaku. Dimulai dari menyajikan nilai tiap pos aset tetap neraca sampai dengan menjelaskan tiap pos aset tetap tersebut. Meskipun sudah mengikuti ketentuan, bukan berarti isi informasi dapat dikatakan benar. Seperti halnya, terjadi kesalahan perhitungan pada rekonsiliasi peralatan dan mesin serta gedung dan bangunan yang tidak sesuai dengan nilai pada neraca. Pada rekonsiliasi dua aset tersebut, saldo awal dan akhir periode, akumulasi penyusutan, serta nilai buku yang masih menunjukkan informasi tahun 


\section{DA}

Vol. 6, No. 1, Oktober 2021

anggaran sebelumnya. Hal ini dapat terjadi dikarenakan ketika waktu penyusunan laporan keuangan yaitu pada awal tahun 2020, pegawai penyusun laporan keuangan akuntansi melakukan pindah tugas ke satker lain sehingga digantikan oleh pegawai pengelola BMN. Oleh karena itu, dimungkinkan format penyusunan masih memakai tahun sebelumnya dan ada beberapa informasi yang tidak disunting sehingga terjadi kesalahan seperti ini.

\section{SIMPULAN}

Berdasarkan pembahasan pada bab sebelumnya dengan membandingkan antara landasan teori dengan penerapan kebijakan akuntansi aset tetap pada Kantor Pelayanan Perbendaharaan Negara Kotabumi, akhirnya maka peneliti mengambil kesimpulan berikut.

1. Aset tetap pada Satker telah digolongkan berdasarkan kesamaan ciri atau gunanya dalam aktivitas operasional. Menurut CaLK, aset tetap yang dimiliki Satker antara lain tanah, peralatan dan mesin, gedung dan bangunan, serta jalan, irigasi, dan jaringan

2. Aset tetap pada Satker diakui pada saat munculnya hak dan kewajiban, memenuhi kriteria aset tetap dan mencukupi nilai kapitalisasi yang ditentukan.

3. Pengukuran aset tetap yang dilakukan Satker menggunakan biaya perolehan sampai dengan aset tetap dalam kondisi siap pakai. Biaya perolehan dapat dihitung dari jumlah kas/setara kas yang dibayarkan atau nilai wajar dari imbalan lain yang diberikan untuk mendapatkan aset tetap tersebut.

4. Satker menghitung penyusutan aset tetap dengan metode garis lurus. Nilai akumulasi penyusutan selanjutnya disajikan dalam neraca sebagai pengurang nilai perolehan aset tetap.

5. Penyajian neraca pada Satker dilakukan dengan penyajian nilai aset tetap masing-masing klasifikasi yang kemudian dikurangi dengan akumulasi penyusutan yang telah dihitung. Pengungkapan aset tetap secara umum telah jelas, namun ada beberapa informasi yang tidak sesuai seperti pada rekonsiliasi peralatan dan mesin serta gedung dan bangunan.

Saran yang dapat peneliti sampaikan adalah sebaiknya mengurangi kesalahan pada proses pencatatan dan penyusunan laporan keuangan agar tidak terdapat ketidaksesuaian informasi aset tetap pada neraca dengan informasi yang diungkapkan dalam Catatan atas Laporan Keuangan. Yang dapat dilakukan dengan pendalaman kompetensi singkat mengenai penyusunan laporan keuangan kepada pegawai yang bertugas ketika akhir tahun anggaran atau awal tahun anggaran berikutnya sebelum dimulainya jadwal penyusunan dan dilakukan pengecekan ulang sebelum laporan keuangan satuan kerja diserahkan. 
Lugas Brillian dan Agus Sunarya Sulaeman: Implementasi Kebijakan Akuntansi................. 
Vol. 6, No. 1, Oktober 2021

\section{DAFTAR PUSTAKA}

Komite Standar Akuntansi Pemerintahan. 2014. Buletin Teknis Standar Akuntansi Pemerintahan Nomor 15 tentang Akuntansi Aset Tetap Berbasis Akrual.

Pemerintah Republik Indonesia. 2010. Peraturan Pemerintah Republik Indonesia Nomor 71 Tahun 2010 tentang Standar Akuntansi Pemerintah.

Kementerian Keuangan. 2016. Peraturan Menteri Keuangan Nomor 181/PMK.06/2016 tentang Penatausahaan Barang Milik Negara.

Kementerian Keuangan. 2016. Peraturan Menteri Keuangan Nomor 224/PMK.05/2016 tentang Perubahan atas Peraturan Menteri Keuangan Nomor 219/PMK.05/2013 tentang Kebijakan Akuntansi Pemerintah Pusat

Kementerian Keuangan. 2017. Peraturan Menteri Keuangan Nomor 65/PMK.06/2017 tentang Penyusutan Barang Milik Negara Berupa Aset Tetap pada Entitas Pemerintah Pusat.

Kementerian Keuangan. 2013. Peraturan Menteri Keuangan Nomor 59/PMK.06/2013 tentang Tabel Masa Manfaat dalam Rangka Penyusutan Barang Milik Negara Berupa Aset Tetap pada Entitas Pemerintah Pusat. 